\title{
Process design and economic studies of two-step fermentation for production of ascorbic acid
}

\author{
Shi Min Lim ${ }^{1}$ - Michelle Siao Li Lau ${ }^{1}$ - Edward Ing Jiun Tiong ${ }^{1}$ Mun Min Goon ${ }^{1}$. Roger Jhee Cheng Lau ${ }^{1}$. \\ Wan Sieng Yeo ${ }^{1}$. $\cdot$ Sie Yon Lau ${ }^{1}\left[{ }^{1} \cdot\right.$ Nabisab Mujawar Mubarak $^{1}{ }^{(0)}$
}

Received: 7 November 2019 / Accepted: 26 March 2020 / Published online: 5 April 2020

(c) Springer Nature Switzerland AG 2020

\begin{abstract}
The current study presents the conceptual design of a chemical plant for an annual production of 500 tonne ascorbic acid or Vitamin C with a high purity of $95 \%$ via fermentation of D-sorbitol. In this study, two-step fermentation with a single culture process is operated with a proper ISO 14000 Environmental Management procedure. A process flow diagram of the processing plant and the plant-wide simulation flowsheet that was generated by SuperPro Designer Simulation software, as well as the material and energy balances are also depicted. Meanwhile, the process is optimized through the recycling of sorbose and heat integration. By recycling sorbose, the production of ascorbic acid has increased by $24 \%$ while the total energy consumption had reduced by $20 \%$ after heat integration. Furthermore, economic and sensitivity analysis was performed to calculate the profitability of the plant and predict the effect of market conditions on the investments. After the economic analysis, total capital investment and total production cost for the best scenario were found to be roughly USD 52 million and USD 43 million, respectively with a return on investment of $78.73 \%$ and a payback period of 1.17 years since the selling price of Vitamin $C$ is high.
\end{abstract}

Keywords Ascorbic acid · SuperPro Designer · Fermentation · Biomass - Esterification · Economic analysis

$\begin{array}{llll}\text { Abbreviation } & & \mathrm{NaOH} & \text { Sodium hydroxide } \\ \mathrm{Cc} & \text { Concentration of biomass } & \mathrm{NPV} & \text { Net present value } \\ \mathrm{CO}_{2} & \text { Carbon dioxide } & \mathrm{OL} & \text { Operating labour } \\ \mathrm{Cp} & \text { Specific heat capacity } & \mathrm{OS} & \text { Operating supervision } \\ \mathrm{CSTR} & \text { Continuous stirred tank reactor } & \mathrm{PE} & \text { Purchased equipment } \\ \mathrm{DC} & \text { Direct cost } & \mathrm{PED} & \text { Purchased equipment delivered } \\ \mathrm{FC} & \text { Fixed charges } & \mathrm{P \& ID} & \text { Piping and instrumentation diagram } \\ \mathrm{FCl} & \text { Fixed capital investment } & \mathrm{POC} & \text { Plant overhead cost } \\ \mathrm{GCE} & \text { Glassy carbon electrode } & \mathrm{Pt} & \text { Platinum } \\ \mathrm{GE} & \text { General expenses } & \mathrm{ROI} & \text { Return on investment } \\ \mathrm{H} & \text { Water } & \mathrm{SF} & \text { Scale factor } \\ \mathrm{IC} & \text { Indirect cost } & \mathrm{T} & \text { Temperature } \\ \mathrm{MC} & \text { Maintenance and repairs cost } & \mathrm{TC} & \text { Critical temperature } \\ \mathrm{MnOx}-\mathrm{MoOx} & \text { Manganese and molybdenum mixed } & \mathrm{TCl} & \text { Total capital investment } \\ & \text { oxides } & \mathrm{TMC} & \text { Total manufacturing cost } \\ \mathrm{NaHCO}_{3} & \text { Sodium bicarbonate } & \mathrm{TPC} & \text { Total production cost }\end{array}$

$\triangle$ Wan Sieng Yeo, christineyeo@curtin.edu.my| ${ }^{1}$ Department of Chemical Engineering, Curtin University Malaysia, CDT 250, 8009 Miri, Sarawak, Malaysia. 
V Working volume of fermenter

VPC Variable production cost

\section{Introduction}

Ascorbic acid (Vitamin C) is the most abundant natural hydro-soluble antioxidant used as a dietary supplement for the human [1], and it exists in various fruits and vegetables such as lemons, oranges, and broccoli. Also, it is an essential cofactor for various metalloenzymes in the human body [2]. Besides, ascorbic acid is required by the agriculture, food, beverage and pharmaceutical industries due to its antioxidant properties. The largest consumer of ascorbic acid is the pharmaceutical industry, which is one-third of its total production. The market demand of ascorbic acid has grown steadily in the Asia Pacific region, including China, Japan, and India, followed by Europe and North America due to the increasing awareness of the public towards a healthy and quality lifestyle. Based on the global Vitamin C report, the global revenue of ascorbic acid market has grown drastically from USD 1070 million in the year 2014 to USD 1280 million in the year 2017, with an average annual growth rate of $6.16 \%$. Moreover, it continues to grow and reach USD 1770 million by the year 2022 .

Ascorbic acid can be synthesized via the Reichstein process or two-step fermentation process with a single or mixed culture [3]. In this plant design, the two-step fermentation process with a single culture is selected since it is environmental-friendly, as well as it has lesser toxicity and lower cost as compared to the Reichstein process [4]. By-products produced from chemical reactions of the selected process are sodium hydroxide $(\mathrm{NaOH})$ and carbon dioxide $\left(\mathrm{CO}_{2}\right)$. Meanwhile, the concentrated sulphuric acid is the hazardous chemical involved in this process. Besides, the water $\left(\mathrm{H}_{2} \mathrm{O}\right)$ released from the process are sent to a wastewater treatment plant before it is discharged, which is in accordance with the Environmental Quality Act 1974 [5]. The objective of this study is to design an ascorbic acid production plant with a capacity of 500 tonne per year, $60 \%$ target product recovery, and high purity of $95 \%$.

\section{Materials and Method}

Ascorbic acid is produced from D-sorbitol, a sugar alcohol that can be obtained from various feedstock such as corn, cassava and wheat. Sorbitol is commonly used in the industrial manufacturing of toothpaste, toiletries, food and ascorbic acid. The global sorbitol production capacity is approximately 500 kilo tonne in the year 2013 from China as the largest producer, followed by the United States and Western Europe. The price of $70 \%$ sorbitol solution of pharmaceutical grade is approximately USD 500 per tonne. The market size of sorbitol was around 1.85 million tonne in the year 2015. It is expected to reach 2.4 million tonne by the year 2023, with a compound annual growth rate of $3.5 \%$ from the years 2016 to 2023 . The major sorbitol producer companies in the market are Archer Daniels Midland, Cargill, Ingredion, Roquette and Tereos.

\subsection{Raw materials and prices}

The feedstocks to produce ascorbic acid include corn, wheat, molasses and D-sorbitol. Meanwhile, the current price for corn is USD 146 per tonne, wheat is USD 232 per tonne, molasses is USD 261 per tonne, and sorbitol is approximately USD 500 per tonne. Pre-treatment is required to extract glucose from corn, molasses and wheat before the conversion of glucose into D-sorbitol.

\subsection{Process technology selection}

The three available process technologies used to produce ascorbic acid are the Reichstein process, the twostep fermentation with a single culture, and the two-step fermentation with a mixed culture. These process technologies have a similar overall yield of production, which is $60 \%$. However, the two-step fermentation has higher efficiency and product quality than the Reichstein process [6]. In terms of process technologies economy, the atom economy values for the Reichstein process and two-step fermentation are 0.6424 and 0.5383 , respectively. Atom economy is the conversion efficiency of a chemical process in terms of all atoms involved and the desired products produced. Lower capital and operating costs of the two-step fermentation process outweigh its lower atom economy; therefore, the overall revenue of the two-step fermentation is higher than the Reichstein process. The calculation of atom economy for the two-step fermentation process is shown in Table a1 in the Appendix.

The chemical equation for the Reichstein process is shown as Eq. (1):

$$
\begin{gathered}
\mathrm{C}_{6} \mathrm{H}_{14} \mathrm{O}_{6}+1 / 2 \mathrm{O}_{2}+\mathrm{NaHCO}_{3} \rightarrow \mathrm{C}_{6} \mathrm{H}_{8} \mathrm{O}_{6} \\
+\mathrm{NaOH}+\mathrm{CO}_{2}+2 \mathrm{H}_{2}+\mathrm{H}_{2} \mathrm{O}
\end{gathered}
$$

Sorbitol + Oxygen + Sodium bicarbonate $\rightarrow$ Sorbose + Sodium hydroxide + Carbon dioxide + Hydrogen + Water.

The chemical equation for the two-step fermentation process (for a single culture and a mixed culture) is shown as Eq. (2): 


$$
\begin{array}{r}
\mathrm{C}_{6} \mathrm{H}_{14} \mathrm{O}_{6}+3 / 2 \mathrm{O}_{2}+\mathrm{Na}_{2} \mathrm{CO}_{3}+\mathrm{NaHCO}_{3} \\
\rightarrow \mathrm{C}_{6} \mathrm{H}_{8} \mathrm{O}_{6}+3 \mathrm{NaOH}+2 \mathrm{CO}_{2}+2 \mathrm{H}_{2} \mathrm{O}
\end{array}
$$

Reichstein process has a higher conversion efficiency of reactant to products as compared to the two-step fermentation process. However, the capital and operating costs of two-step fermentation are much lower than the Reichstein process, and this outweighs its lower atom economy and conversion efficiency [7]. Moreover, in the Reichstein process, sorbitol in the conventional batch fermenter inhibits the growth of bacteria and high initial concentration of sorbitol decrease the rate of oxidation [8]. The overall production cost of the two-step fermentation process is twothird of the Reichstein process. In other words, the total revenue of the two-step fermentation process is higher.

Besides, as shown in the process flow diagram (Fig. 6) in Appendix, the two-step fermentation process involves lesser steps than the Reichstein process; thus, it reduces energy and water consumptions. Also, the two-step fermentation process operates at lower temperature and pressure conditions, which is cheaper and safer than the Reichstein process. Furthermore, from the Eq. (2), the two-step fermentation process replaces the chemical reaction of sorbose to 2-keto-gulonic acid with fermentation that reduces the use of harmful solvents and reagents such as acetone. The cost of waste disposal for the Reichstein process is also much higher compared to the two-step fermentation process since the amount of waste produced is significant [9]. In conclusion, the two-step fermentation is simpler with lesser steps, lower capital and operating cost, as well as it works at a lower temperature and pressure conditions than the Reichstein process. Hence, the two-step fermentation with a single culture or a mixed culture is more preferred than the Reichstein process.

Next, the single culture and the mixed culture of the two-step fermentation process are studied and compared. In the second fermenter, the single culture only uses one bacterium, whereas the mixed culture uses two different bacteria. However, the mixed culture is hard to be detected and controlled the contamination of the fermentation. Moreover, it is difficult to obtain an optimum balance among the microorganisms involved [10], and the cultivation of two different bacteria requires more time and space. Therefore, the two-step fermentation with a single culture is chosen since it has a lower production cost with higher efficiency, and it is easier to control and monitor the fermentation process than the mixed culture.

\subsection{Process description}

As shown in the simulated flow sheet attached in Fig. 1, $70 \%$ of sorbitol solution is fed to the first fermenter (FR-101) along with ammonia, water and air to undergo oxidative fermentation under $30^{\circ} \mathrm{C}$ and $\mathrm{pH} 6$ with an initial concentration of $200 \mathrm{~g} / \mathrm{L}$ [11]. In the first fermenter, the sorbitol is converted to sorbose by Gluconobacter oxydans [12] in $14 \mathrm{~h}$ for $98 \%$ conversion [11]. Combination of glassy carbon

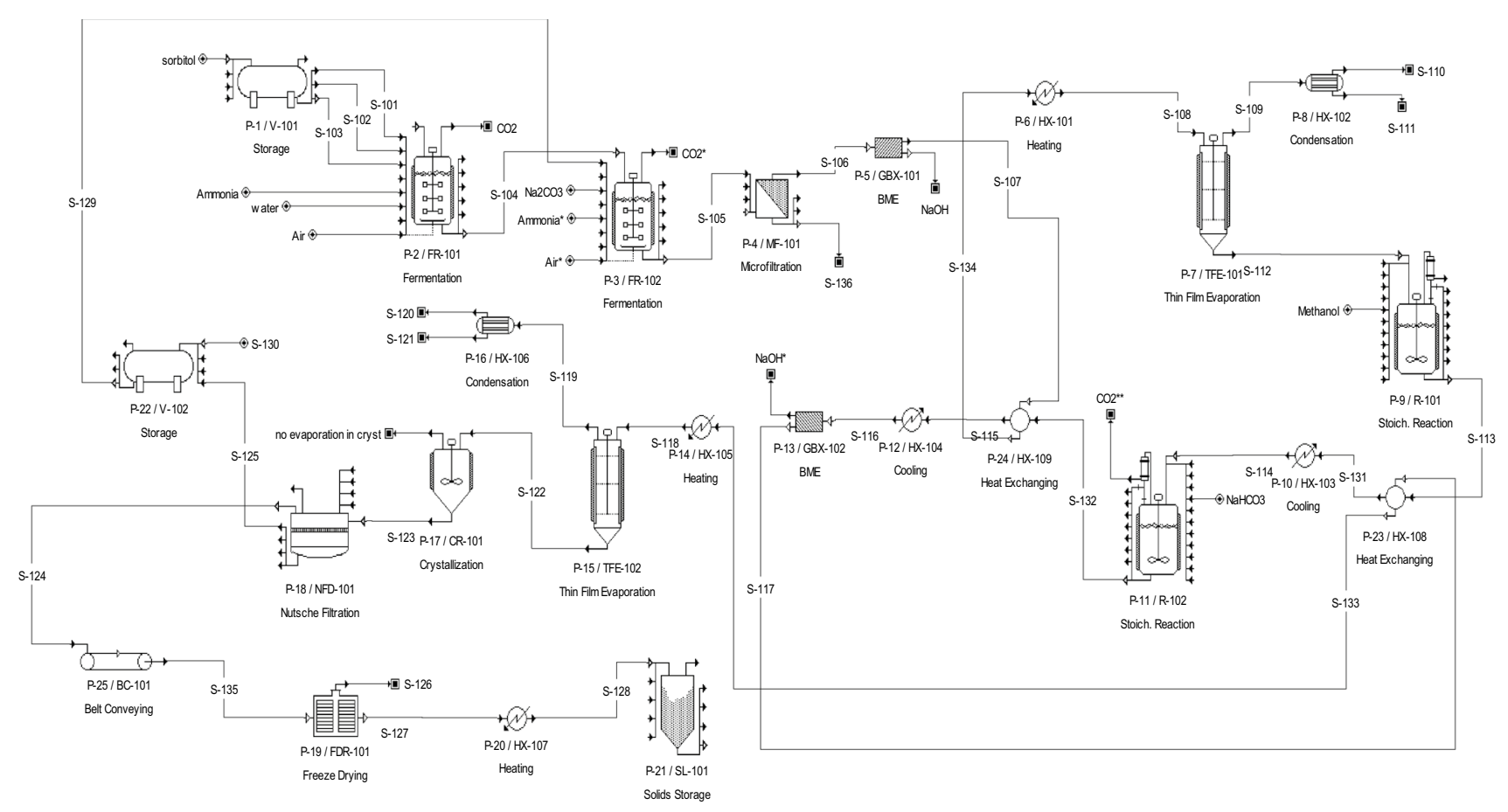

Fig. 1 Simulated flow sheet from SuperPro Design 
Table 1 Thermodynamics and chemistry data for equipment

\begin{tabular}{|c|c|}
\hline Equipment & Process chemistry and thermodynamics \\
\hline $\begin{array}{l}\text { Fermenter } \\
\text { FR-101 }\end{array}$ & 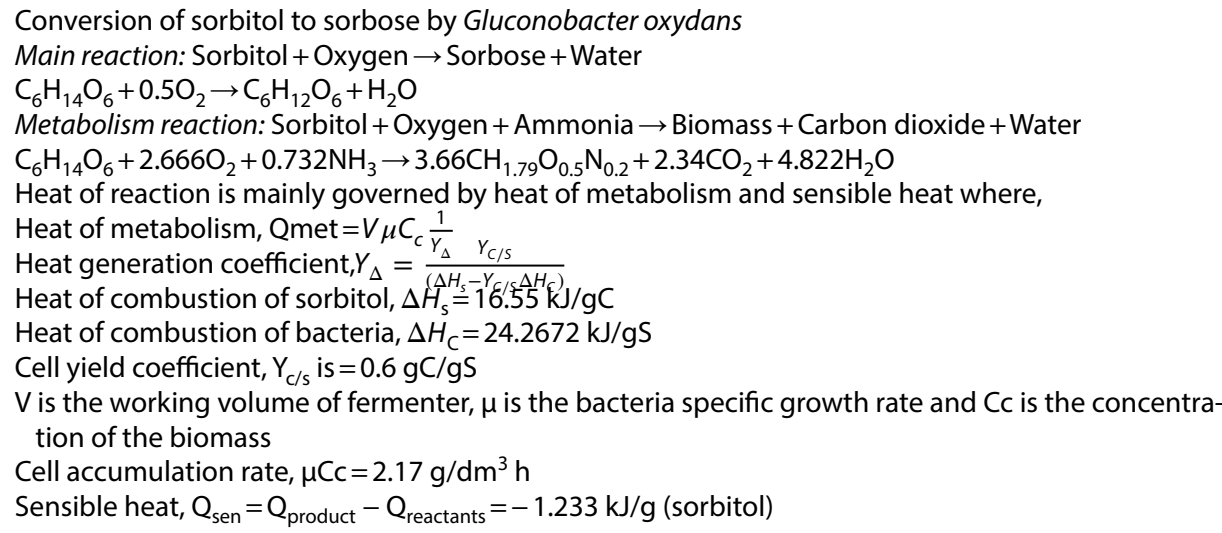 \\
\hline $\begin{array}{l}\text { Fermenter } \\
\text { FR-102 }\end{array}$ & $\begin{array}{l}\text { Conversion of sorbose to sodium keto-gluconic acid by Pseudoglyconobacter Saccharoketogenes } \\
\text { Main Reaction: Sorbose + Oxygen + Sodium carbonate } \rightarrow \text { Sodium keto-gluconic acid + Water + Car- } \\
\text { bon dioxide } \\
\mathrm{C}_{6} \mathrm{H}_{12} \mathrm{O}_{6}+\mathrm{O}_{2}+1 / 2 \mathrm{Na}_{2} \mathrm{CO}_{3} \rightarrow \mathrm{C}_{6} \mathrm{H}_{9} \mathrm{NaO}_{7}+3 / 2 \mathrm{H}_{2} \mathrm{O}+1 / 2 \mathrm{CO}_{2} \\
\text { Metabolism Reaction: Sorbose }+\mathrm{Oxygen}+\mathrm{Ammonia}^{\rightarrow} \text { Biomass }+ \text { Carbon dioxide + Water } \\
\mathrm{C}_{6} \mathrm{H}_{12} \mathrm{O}_{6}+0.73 \mathrm{NH}_{3}+2.157 \mathrm{O}_{2} \rightarrow 3.66 \mathrm{CH}_{1.79} \mathrm{O}_{0.5} \mathrm{~N}_{0.2}+2.34 \mathrm{CO}_{2}+3.804 \mathrm{H}_{2} \mathrm{O} \\
\mathrm{Heat} \text { of reaction is mainly governed by heat of metabolism and sensible heat where sensible heat, } \\
\mathrm{Q}_{\text {sen }}=-2.691 \mathrm{~kJ} / \mathrm{g} \text { (sorbose) }\end{array}$ \\
\hline $\begin{array}{l}\text { Bipolar Membrane Electrodialysis } \\
\text { GBX-101 }\end{array}$ & $\begin{array}{l}\text { Conversion of sodium keto-gluconic acid to keto-gluconic acid through hydrolysis } \\
\text { Sodium keto-gluconic acid }+ \text { Water } \rightarrow \text { Keto-gluconic acid }+ \text { Sodium hydroxide } \\
\mathrm{C}_{6} \mathrm{H}_{9} \mathrm{NaO}_{7}+\mathrm{H}_{2} \mathrm{O} \rightarrow \mathrm{C}_{6} \mathrm{H}_{10} \mathrm{O}_{7}+\mathrm{NaOH} \\
\text { Heat of reaction: }-629 \mathrm{~J} / \mathrm{g} \text { (Sodium keto-gluconic acid) }\end{array}$ \\
\hline $\begin{array}{l}\text { Reactor } \\
\text { R-101 }\end{array}$ & $\begin{array}{l}\text { Conversion of keto-gluconic acid to methyl gluconate through esterification process } \\
\text { Keto-gluconic acid }+ \text { Methanol } \rightarrow \text { Methyl gluconate }+ \text { Water } \\
\mathrm{C}_{6} \mathrm{H}_{10} \mathrm{O}_{7}+\mathrm{CH}_{3} \mathrm{OH} \rightarrow \mathrm{C}_{7} \mathrm{H}_{12} \mathrm{O}_{7}+\mathrm{H}_{2} \mathrm{O} \\
\text { Heat of reaction: }-240 \mathrm{~J} / \mathrm{g} \text { (Keto-gluconic acid) }\end{array}$ \\
\hline $\begin{array}{l}\text { Reactor } \\
\text { R-102 }\end{array}$ & $\begin{array}{l}\text { Conversion of methyl gluconate to sodium ascorbate } \\
\text { Methyl gluconate }+ \text { Sodium bicarbonate } \rightarrow \text { Sodium ascorbate }+ \text { Methanol + Water }+ \text { Carbon dioxide } \\
\mathrm{C}_{7} \mathrm{H}_{12} \mathrm{O}_{7}+\mathrm{NaHCO} \mathrm{Na}_{3} \rightarrow \mathrm{C}_{6} \mathrm{H}_{7} \mathrm{O}_{6} \mathrm{Na}+\mathrm{CH}_{3} \mathrm{OH}+\mathrm{H}_{2} \mathrm{O}+\mathrm{CO}_{2} \\
\text { Heat of reaction: }-4.298 \mathrm{~kJ} / \mathrm{g} \text { (Methyl gluconate) }\end{array}$ \\
\hline $\begin{array}{l}\text { Bipolar Membrane Electrodialysis } \\
\text { GBX-102 }\end{array}$ & $\begin{array}{l}\text { Recovery of ascorbic acid from sodium ascorbate through hydrolysis reaction } \\
\text { Sodium ascorbate }+ \text { Water } \rightarrow \text { Sodium hydroxide }+ \text { Ascorbic Acid } \\
\mathrm{C}_{6} \mathrm{H}_{7} \mathrm{O}_{6} \mathrm{Na}+\mathrm{H}_{2} \mathrm{O} \rightarrow \mathrm{NaOH}+\mathrm{C}_{6} \mathrm{H}_{8} \mathrm{O}_{6}\end{array}$ \\
\hline
\end{tabular}

electrode with molybdenum and manganese oxides makes Gluconobacter oxydans. For these bacterial strains, platinum $(\mathrm{Pt})$ acts as an immobilization matrix (GCE/MnOx-MoOx/Pt) where GCE stands for Glassy carbon electrode, and $\mathrm{MnOx}$ MoOx is the manganese and molybdenum mixed oxides.

Before entering the second fermenter, the biomass produced in the first fermenter is being removed by passing the fermentation broth through a microfilter. Later, this fermentation broth is fermented in the second fermenter (FR102) by Pseudoglyconobacter Saccharoketogenes for $72 \mathrm{~h}$ to produce sodium keto-gluconic acid [13]. In this fermenter, the conversion of sorbose to sodium keto-gluconic acid is $76 \%$ [14]. The slurry from the fermenter is then transferred to a microfilter (MF-101) to separate biomass produced by the bacteria. Approximately $1 \%$ of the liquid solution is a loss through the removal of biomass using a microfilter. Pseudoglyconobacter Saccharoketogenes can oxidize primary alcohol, secondary alcohol, aldehydes and polysaccharides.

Then, the recovery of 2-keto-gulonic acid from sodium keto-gluconic acid is made by a bipolar membrane electrodialysis (GBX-101) through the exchanges of cation and anion with water molecules [15]. Next, the recovered 2-keto-gulonic acid is fed to an evaporator (TFE-101) to remove the water before entering a continuous stirred tank reactor, CSTR (R-101). The purpose of removing water is to increase forward reaction in R-101 since water is a product in the reaction [16]. In the CSTR (R-101), 2-ketogulonic acid undergoes esterification process with methanol at $64{ }^{\circ} \mathrm{C}$ to produce methyl gluconate [17]. 
Table 2 Formula for mass and energy balances

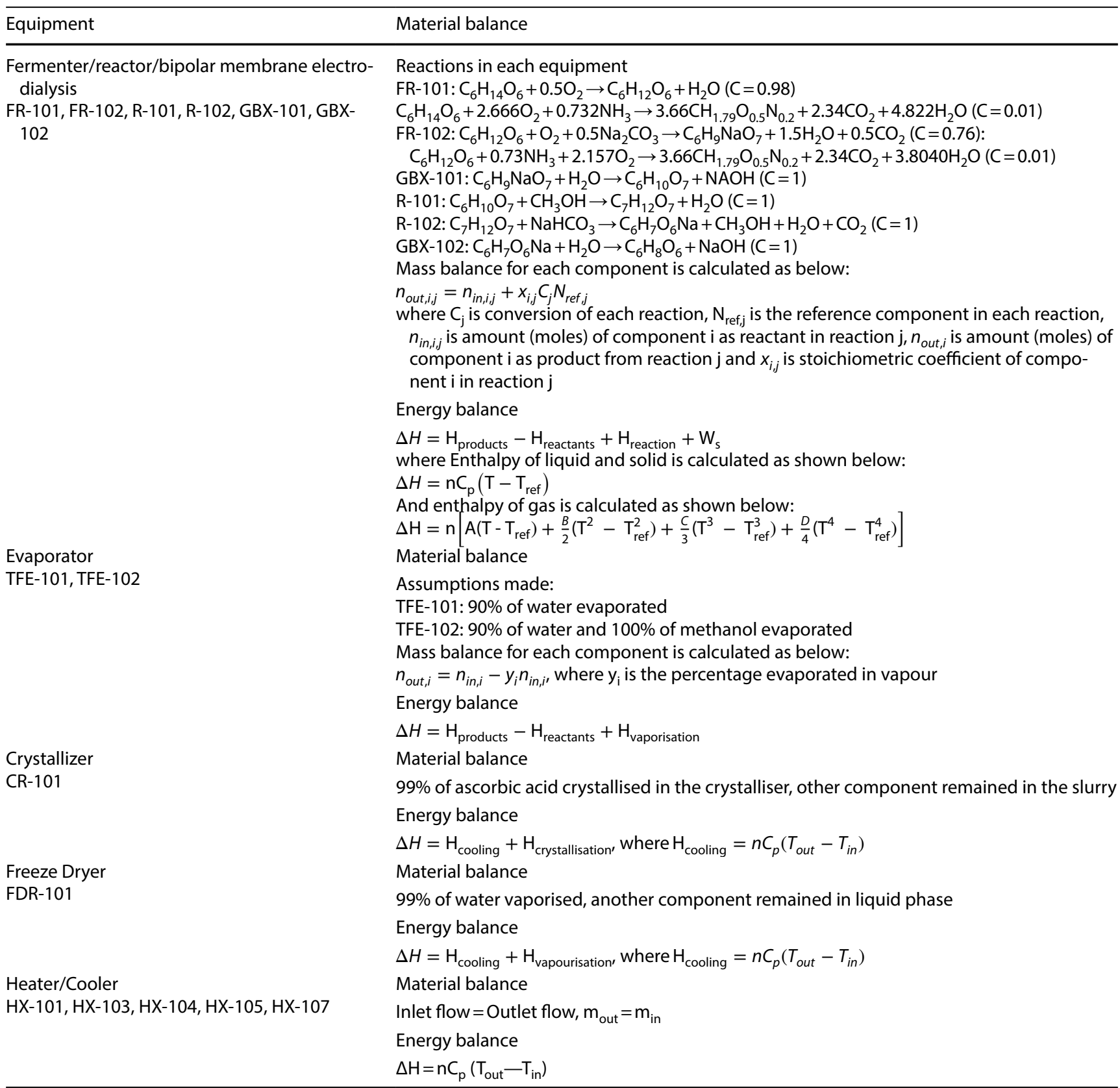

Before reacting methyl gluconate with sodium carbonate in R-102, 2-ketogulonic acid is cooled to $30^{\circ} \mathrm{C}$ by a cooler (HX-103). Methyl gluconate reacts with sodium carbonate to form sodium ascorbate. Then, sodium ascorbate is fed to another bipolar membrane electrodialysis (GBX-102) to recover ascorbic acid. The water produced in the reactor is evaporated in a vacuum evaporator (TFE-102) before feeding the ascorbic acid to crystallization process (CR-101) for $54 \mathrm{~h}$ at $4{ }^{\circ} \mathrm{C}$. Solid ascorbic acid is then freeze-dried in a freeze dryer (FDR-101) to $-35^{\circ} \mathrm{C}$ after filtration (NFD-101) process due to the heat sensitivity properties of a solid ascorbic acid [18]. Since the optimum storage temperature for solid ascorbic acid is $4^{\circ} \mathrm{C}$, it is heated before feeding into a storage tank.

The production of ascorbic acid involves a series of the biochemical and chemical reaction. This reaction produces the intermediate products such as sorbose, sodium keto-gluconic acid, keto-gluconic acid, methyl gluconate, and sodium ascorbate. On the other hand, purification of ascorbic acid requires 
Table 3 Equipment-wise material balance

\begin{tabular}{|c|c|c|c|c|}
\hline \multirow[t]{2}{*}{ Equipment } & \multirow[t]{2}{*}{ Stream no. } & \multicolumn{3}{|c|}{ Mass flow rate $(\mathrm{kg} / \mathrm{h})$} \\
\hline & & Manual & SuperPro & $\%$ Error $^{a}$ \\
\hline & Inlet & & & \\
\hline \multirow{8}{*}{$\begin{array}{l}\text { Fermenter } 1 \\
\text { FR-101 }\end{array}$} & Sorbitol & 32,610 & 32,610 & - \\
\hline & Ammonia & 15 & 16 & 6.2500 \\
\hline & Water & 38,909 & 38,909 & - \\
\hline & Air & 8800 & 9019 & 2.4282 \\
\hline & Outlet & & & \\
\hline & S-104 & 73,458 & 73,458 & - \\
\hline & $\mathrm{CO}_{2}$ & 6877 & 7180 & 4.2200 \\
\hline & Inlet & & & \\
\hline \multirow{9}{*}{$\begin{array}{l}\text { Fermenter } 2 \\
\text { FR-102 }\end{array}$} & S-104 & 73,458 & 73,458 & - \\
\hline & S-129 & 7364 & 7057 & 4.3502 \\
\hline & $\mathrm{Na}_{2} \mathrm{CO}_{3}$ & 6025 & 6025 & - \\
\hline & Ammonia & 4 & 4 & - \\
\hline & Air & 15,725 & 15,725 & - \\
\hline & Outlet & & & \\
\hline & S-105 & 87,668 & 87,668 & - \\
\hline & $\mathrm{CO}_{2}$ & 14,601 & 14,692 & 0.6193 \\
\hline & Inlet & & & \\
\hline \multirow{5}{*}{$\begin{array}{l}\text { Centrifuge } \\
\text { DC-101 }\end{array}$} & S-105 & 87,668 & 87,668 & - \\
\hline & Outlet & & & \\
\hline & S-106 & 85,860 & 85,860 & - \\
\hline & Biomass & 1808 & 1808 & - \\
\hline & Inlet & & & \\
\hline \multirow{5}{*}{$\begin{array}{l}\text { BME } 1 \\
\text { GBX-101 }\end{array}$} & S-106 & 85,860 & 85,860 & - \\
\hline & Outlet & & & \\
\hline & S-107 & 81,359 & 81,359 & - \\
\hline & $\mathrm{NaOH}$ & 4502 & 4502 & - \\
\hline & Inlet & & & \\
\hline \multirow{5}{*}{$\begin{array}{l}\text { Evaporator } \\
\text { TFE-101 }\end{array}$} & S-108 & 81,359 & 81,359 & - \\
\hline & Outlet & & & \\
\hline & S-109 & 46,909 & 46,909 & - \\
\hline & S-112 & 34,450 & 34,450 & - \\
\hline & Inlet & & & \\
\hline \multirow{5}{*}{$\begin{array}{l}\text { CSTR } 1 \\
\text { R-101 }\end{array}$} & S-112 & 34,450 & 34,450 & - \\
\hline & $\mathrm{CH}_{3} \mathrm{OH}$ & 3606 & 3606 & - \\
\hline & Outlet & & & \\
\hline & S-113 & 38,056 & 38,056 & - \\
\hline & Inlet & & & \\
\hline \multirow{5}{*}{$\begin{array}{l}\text { CSTR } 2 \\
\text { R-102 }\end{array}$} & S-114 & 38,056 & 38,056 & - \\
\hline & $\mathrm{NaHCO}_{3}$ & 9455 & 9455 & - \\
\hline & Outlet & & & \\
\hline & S-115 & 42,577 & 42,558 & 0.0446 \\
\hline & $\mathrm{CO}_{2}$ & 4954 & 4954 & - \\
\hline
\end{tabular}

Table 3 (continued)

\begin{tabular}{|c|c|c|c|c|}
\hline \multirow[t]{2}{*}{ Equipment } & \multirow[t]{2}{*}{ Stream no. } & \multicolumn{3}{|c|}{ Mass flow rate $(\mathrm{kg} / \mathrm{h})$} \\
\hline & & Manual & SuperPro & $\%$ Error $^{\mathrm{a}}$ \\
\hline & Inlet & & & \\
\hline \multirow{5}{*}{$\begin{array}{l}\text { BME } 2 \\
\text { GBX-102 }\end{array}$} & S-116 & 42,557 & 42,557 & - \\
\hline & Outlet & & & \\
\hline & S-117 & 38,056 & 38,056 & - \\
\hline & $\mathrm{NaOH}$ & 4502 & 4502 & - \\
\hline & Inlet & & & \\
\hline \multirow{5}{*}{$\begin{array}{l}\text { Evaporator } \\
\text { TFE-102 }\end{array}$} & S-118 & 38,056 & 38,056 & - \\
\hline & Outlet & & & \\
\hline & S-119 & 10,122 & 10,122 & - \\
\hline & S-122 & 27,934 & 27,934 & - \\
\hline & Inlet & & & \\
\hline \multirow{4}{*}{$\begin{array}{l}\text { Crystallizer } \\
\text { CR-101 }\end{array}$} & S-122 & 27,934 & 27,934 & - \\
\hline & Outlet & & & \\
\hline & S-123 & 27,934 & 27,934 & - \\
\hline & Inlet & & & \\
\hline \multirow{5}{*}{$\begin{array}{l}\text { Filtration } \\
\text { NFD-101 }\end{array}$} & S-123 & 27,934 & 27,934 & - \\
\hline & Outlet & & & \\
\hline & S-124 & 19,012 & 19,012 & - \\
\hline & S-125 & 8922 & 8922 & - \\
\hline & Inlet & & & \\
\hline \multirow{4}{*}{$\begin{array}{l}\text { Freeze dryer } \\
\text { FRD-101 }\end{array}$} & S-124 & 19,012 & 19,012 & - \\
\hline & Outlet & & & \\
\hline & S-126 & 72 & 72 & - \\
\hline & S-127 & 18,941 & 18,941 & - \\
\hline
\end{tabular}

${ }^{a} \%$ error is defined as the percentage of relative error between the results from SuperPro software and the manual calculation

both chemical and physical processes, which involve heat and mass transfers. Therefore, the chemical process and thermodynamics are crucial to determine the operating conditions and the type of equipment used. The thermodynamics and chemistry data for each equipment in a sequence is listed in Table 1. Meanwhile, the thermodynamics properties of each component are presented in Table a.2 in the Appendix.

\subsection{Process optimization and heat integration}

Heat integration is performed to minimize the consumption of energy and the total operating cost. Since the production of ascorbic acid is a batch process, the period where process streams are available for heat exchange is different. Therefore, heat exchanger network only performs on process stream that is available for heat exchange at the same time. 
Table 4 Overall and section wise material balance comparison

\begin{tabular}{|c|c|c|c|}
\hline \multirow[t]{2}{*}{ Description } & \multicolumn{3}{|c|}{ Mass flow rate $(\mathrm{kg} / \mathrm{h})$} \\
\hline & Manual & SuperPro & $\%$ Error $^{\mathrm{a}}$ \\
\hline \multicolumn{4}{|c|}{ Overall mass balance } \\
\hline Input & 115,152 & 115,371 & 0.1898 \\
\hline Output & 113,287 & 113,681 & 0.3466 \\
\hline \multicolumn{4}{|c|}{ Section wise mass balance } \\
\hline \multicolumn{4}{|c|}{ Fermentation } \\
\hline Input & 102,090 & 102,309 & 0.2141 \\
\hline Output & 109,147 & 109,541 & 0.3597 \\
\hline \multicolumn{4}{|l|}{ Reaction } \\
\hline Input & 100,730 & 100,730 & - \\
\hline Output & 100,749 & 100,730 & 0.0189 \\
\hline \multicolumn{4}{|l|}{ Purification } \\
\hline Input & 42,557 & 42,558 & 0.0023 \\
\hline Output & 38,590 & 38,590 & - \\
\hline
\end{tabular}

${ }^{\mathrm{a}} \%$ Error is defined as the percentage of relative error between the results from SuperPro software and the manual calculation

Table 5 Equipment-wise energy balance

\begin{tabular}{llll}
\hline Equipment & \multicolumn{3}{l}{ Equipment duty (kJ/batch) } \\
\cline { 2 - 4 } & Manual & SuperPro & \% Error $^{\text {a }}$ \\
\hline Fermenter 1, FR-101 & $43,522,411$ & $42,581,232$ & 2.21 \\
Fermenter 2, FR-102 & $69,445,108$ & $75,205,656$ & $7.66^{*}$ \\
Centrifuge, DC-101 & 272,160 & 272,160 & - \\
BME, GBX-101 & $15,762,759$ & $15,729,747$ & 0.21 \\
Heater, HX-101 & $15,258,742$ & $15,258,742$ & - \\
Evaporator, TFE-101 & $112,781,656$ & $112,787,158$ & - \\
CSTR 1, R-101 & $7,554,563$ & $7,358,969$ & 2.66 \\
Heat exchanger, HX-108 & $1,789,199$ & $1,789,404$ & 0.01 \\
Cooler, HX-103 & 745,500 & 745,294 & 0.03 \\
CSTR 2, R-102 & $97,011,299$ & $98,903,820$ & 1.91 \\
Heat exchanger, HX-109 & 486,086 & 461,116 & 5.42 \\
Cooler, HX-104 & 922,030 & 921,929 & 0.01 \\
BME, GBX-102 & $17,329,444$ & $17,695,272$ & 2.07 \\
Heater, HX-105 & $1,057,565$ & $1,057,565$ & - \\
Evaporator, TFE-102 & $22,173,388$ & $22,174,209$ & - \\
Crystallizer, CR-101 & $4,558,570$ & $2,062,880$ & $120.98^{* * *}$ \\
Freeze dryer, FRD-101 & 332,677 & 308,736 & $7.75^{* * *}$ \\
Heater, HX-107 & 321,002 & 321,002 & - \\
\hline * & & & \\
\hline
\end{tabular}

*Difference in mass balance in S-129 results in the difference in energy balance

** The calculations of the heat of crystallization in Superpro Designer might be different we the manual calculations

${ }^{* * *}$ Error in SuperPro Designer as the utility used in freeze dryer is steam as default value

${ }^{\mathrm{a}} \%$ Error is defined as the percentage of relative error between the results from SuperPro software and the manual calculation
Table 6 Equipment and section wise energy balance comparison

\begin{tabular}{llll}
\hline Description & \multicolumn{3}{l}{ Equipment duty (kJ/batch) } \\
\cline { 2 - 4 } & Manual & SuperPro & $\%$ Error $^{\mathrm{a}}$ \\
\hline Overall energy balance & $411,324,159$ & $415,634,891$ & 1.0371 \\
Section wise energy balance & & & \\
$\quad$ Fermentation & $112,967,519$ & $117,786,888$ & 4.0916 \\
Reaction & $252,583,994$ & $254,228,339$ & 0.6468 \\
Purification & $45,772,646$ & $43,619,664$ & 4.9358 \\
\hline
\end{tabular}

${ }^{\mathrm{a}} \%$ Error is defined as the percentage of relative error between the results from SuperPro software and the manual calculation

\subsection{Plant economic analysis}

Economic analysis is done on the plant design of ascorbic acid to determine its total investment, total capital and total operating costs. So, the profitability of the ascorbic acid plant and the percentage return on investment (ROI) can be calculated. Breakeven analysis is also done to determine the payback period of the plant designed. The economic analysis is then assessed based on three scenarios, which are the base case, the best case, and the worst case to increase the preparedness for future emergencies. These cases are compared, and then the most feasible case is chosen.

Since the Vitamin C chemical plant is built to make profits, the cost estimation is essential to be done before the cost-effectiveness of the plant can be evaluated. Method of Guthrie is used for preliminary estimation of the cost estimation for individual equipment. The chemical engineering plant cost index for the year 2017, which is 567.5 is used to determine the purchased equipment and bare module costs. The accuracy of the cost estimation for equipment methods are affected by the project complexity, accuracy of cost information, availability of materials and performance of equipment [20]. The cost estimation for each equipment is done before the designation of each equipment, hence the dimension of the equipment such as height, length and diameter are assumed and predefined. Through SuperPro Designer, most of the equipment specifications such as heat transfer area, volume and area of the equipment can be obtained. The cost for the equipment where its size exceeds the size boundary is calculated as multiple units in series when the specified diameter is too large.

There are three main categories for the calculation of total capital investment, namely direct cost, indirect cost and Fixed Capital Investment (FCl). Direct cost includes cost of purchased equipment and transportation charges for all instrumentation and controls equipment, piping, yard improvements and service facilities. The cost of instrumentation and controls are calculated based on the 
Table 7 Available period for heat sink and heat sources

\begin{tabular}{|c|c|c|c|c|c|c|c|c|}
\hline \multirow[t]{2}{*}{ Type } & \multirow[t]{2}{*}{ Unit } & \multicolumn{2}{|c|}{ Stream } & \multirow[t]{2}{*}{ Mass (kg) } & \multicolumn{2}{|c|}{ Temperature $\left({ }^{\circ} \mathrm{C}\right)$} & \multicolumn{2}{|c|}{ Time (h) } \\
\hline & & Inlet & $\overline{\text { Outlet }}$ & & Inlet & $\overline{\text { Outlet }}$ & Start & End \\
\hline \multirow[t]{3}{*}{ Sink } & HX-101 & S-107 & S-108 & $81,358.65$ & 30 & 90 & 101 & 103 \\
\hline & HX-105 & S-117 & S-118 & $38,056.25$ & 30 & 64 & 101 & 104 \\
\hline & HX-107 & S-127 & S-128 & $18,940.55$ & -35 & 4 & 189 & 191 \\
\hline \multirow[t]{2}{*}{ Source } & HX-103 & S-113 & S-114 & $38,056.48$ & 64 & 30 & 101 & 103 \\
\hline & HX-104 & S-132 & S-116 & $42,557.86$ & 45 & 30 & 101 & 103 \\
\hline
\end{tabular}

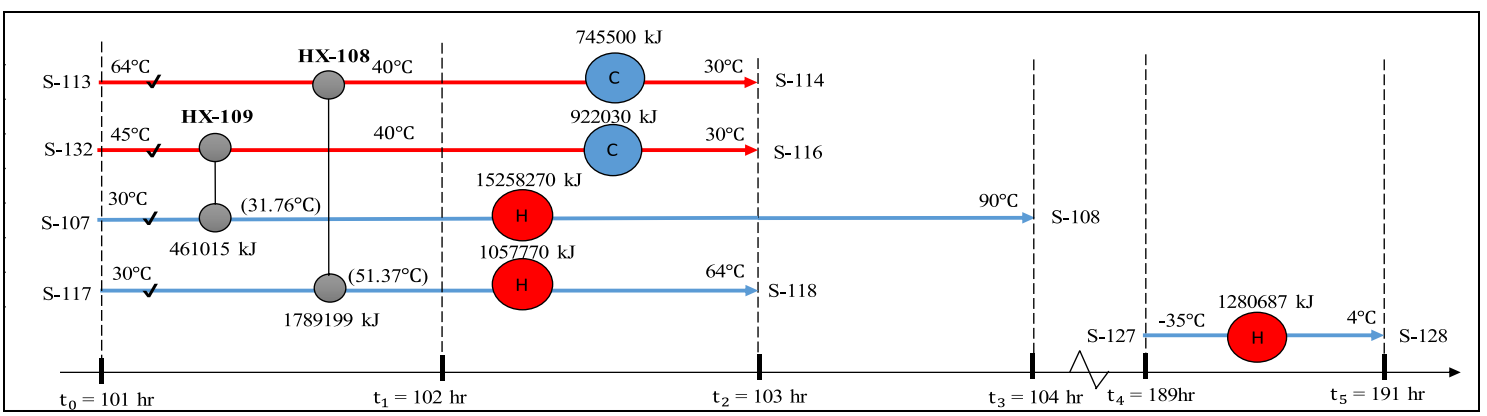

Fig. 2 Overall heat exchanger network for all heat sinks and heat sources at different time intervals

Piping and Instrumentation Diagram (P\&ID) drawn. For the second category, indirect costs include the expenses from construction, legal expenses, contractor's fee, contingency, engineering, and supervision. $\mathrm{FCl}$ is the total summation of direct and indirect cost. As for the working capital, it is approximately $15 \%$ of the Total Capital Investment (TCl). Therefore, the working capital is calculated by using the "Goal Seek" function in Microsoft Excel. Finally, $\mathrm{TCl}$ is obtained by adding the $\mathrm{FCl}$ and working capital. Equations (3) and (4) below show the methodology of TCI calculation.

$\mathrm{FCl}=$ Total direct cost + Total indirect cost

where working capital is $15 \%$ of $\mathrm{TCl}$. Equation (4) is taken from Towler and Sinnott [21].

$T C l=\frac{F C l}{0.85}$

At first, for the estimation of the operating cost, raw materials cost, utilities cost and operating labors cost need to be calculated. Then, these costs are used to calculate Plant Overhead Cost (POC), Total Manufacturing Cost (TMC) and Total Production Cost (TPC). POC includes the costs for raw materials, operating labor, utilities, operating supervision, maintenance, repair cost, operating supplies, laboratory charges, and royalties [22]. Each cost of raw material is obtained from a Sigma-Aldrich manufacturer in an online website and the total cost of equipment is calculated using the CAPCOST software in Microsoft Excel [23].
For the utilities, heat duty consumption of utilities is obtained from the optimized simulation in SuperPro Designer software. Moreover, the cost of utilities for chilled water, cooling water, low-pressure steam, liquid nitrogen, and glycol are also obtained from SuperPro Designer software. Meanwhile, the pricing and tariffs of electricity are obtained from the local electricity company's official website. The electricity usage in the plant is assumed to be medium industrial voltage usage tariff. TMC includes taxes for the property, insurance, financing and depreciation cost. TPC is the summation of POC, TMC and total general expenses such as the administrative expenses, distribution and marketing insurance as well as research and development expenses.

\section{Results and discussion}

\subsection{Process conceptualization and simulation}

The above simulated flow sheet as shown in Fig. 1 was generated by Superpro Designer software. Meanwhile, the stream table obtained from Superpro Designer is attached in Table a. 3 in the Appendix. There are a few simplification and assumptions made to simulate the process in SuperPro Designer. Firstly, the reactions are simulated by entering the conversion value for each reaction only since no data of reaction and growth kinetics is available in the software to simulate the growth of bacteria. As a result, 

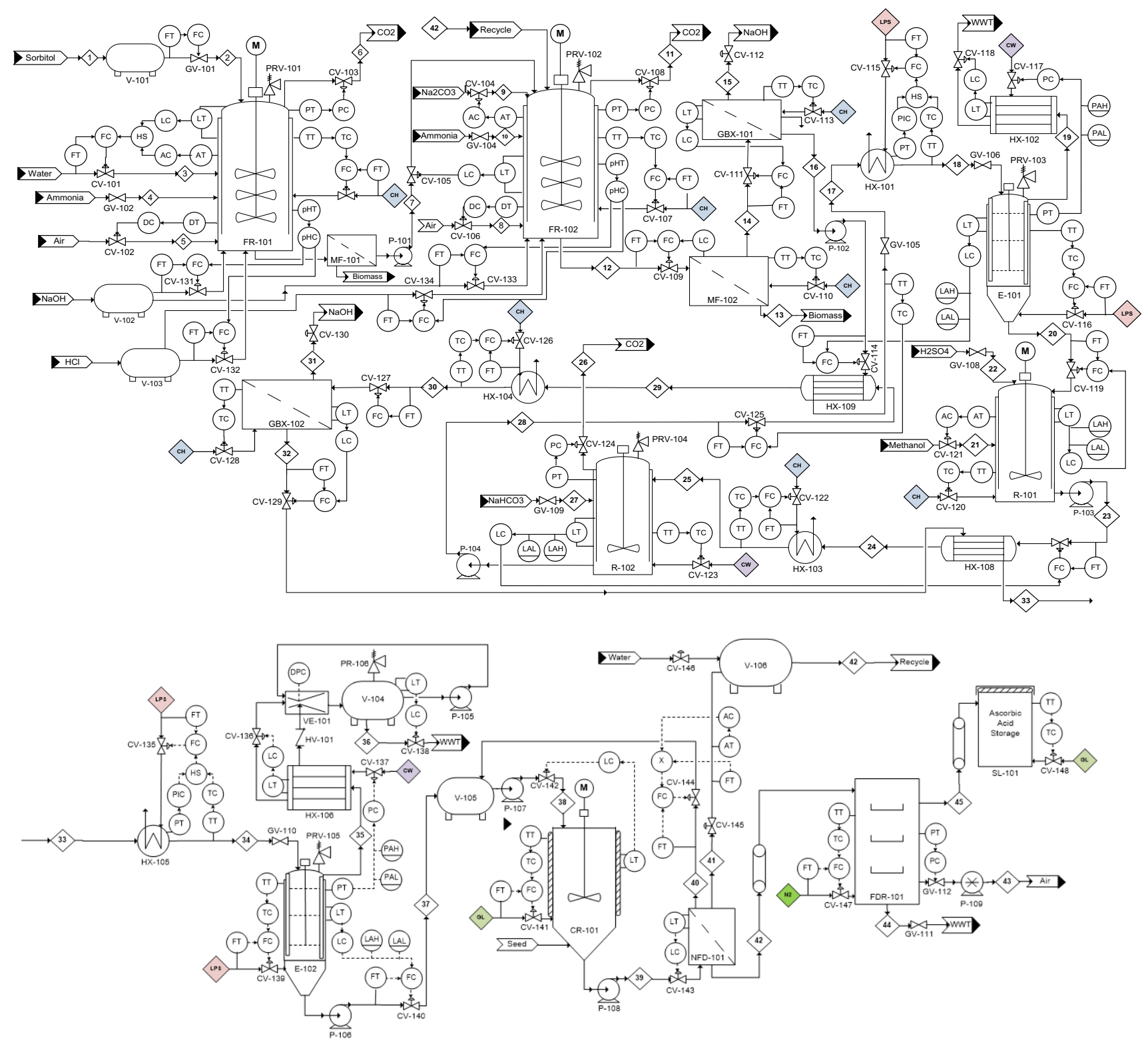

Fig. 3 Piping and instrumentation diagram for ascorbic acid plant

the simulation might be unrealistic as compared with real case situations.

Besides, the data for sorbose, sodium keto-gluconic acid, keto-gluconic acid, methyl gluconate, and sodium ascorbate are unavailable in the component databank. Therefore, their properties and values are manually added to the databank for simulation. Moreover, the properties of methyl gluconate, keto-gluconic acid, sodium ketogluconic acid, keto-gluconic acid, and sodium ascorbate are assumed to be same as the properties of ascorbic acid due to unavailability of component data. Also, mass and energy balances were performed manually to validate the results from SuperPro Designer.

\subsection{Mass and energy balances}

The mass and energy balances from manual calculations and SuperPro Designer are compared, then the percentage error is calculated. If the percentage error is less than $5 \%$, it is acceptable. The formula used to calculate the mass and energy balance are shown in Table 2. The manual calculation for mass and energy balances are performed on several major equipment. As shown in Tables 3 and 4, there is no significant deviation for the mass balance, which the percentage errors do not exceed $5 \%$. The energy balance in each equipment is also calculated and compared with the results from the simulation in Tables 5 and 6 . However, 
Table 8 Lang factors for approximation for capital investment

\begin{tabular}{|c|c|c|c|}
\hline Description & Cost factor & Formula & Total cost (USD) \\
\hline \multicolumn{4}{|l|}{ Direct cost (DC) } \\
\hline Purchased equipment (PE) cost & - & - & $8,615,735$ \\
\hline Delivery cost & 0.1 & $0.1 * P E$ & $86,157,354$ \\
\hline Purchased equipment delivered (PED) & - & - & $9,477,309$ \\
\hline Land & - & - & $6,000,000$ \\
\hline Instrumentation and controls (installed) & - & - & 30,233 \\
\hline Purchased equipment installation & 0.39 & $0.39 *$ PED & $3,696,150$ \\
\hline Piping (installed) & 0.31 & $0.31 *$ PED & $2,937,966$ \\
\hline Electrical (installed) & 0.1 & $0.1 *$ PED & 947,731 \\
\hline Buildings (including services) & 0.29 & $0.29 *$ PED & $2,748,420$ \\
\hline Yard improvements & 0.1 & $0.1^{*} \mathrm{PED}$ & 947,731 \\
\hline \multirow[t]{2}{*}{ Service facilities (installed) } & 0.55 & $0.55^{*}$ PED & $5,212,520$ \\
\hline & & Total direct plant cost $(\Sigma D C)$ & $126,771,149$ \\
\hline \multicolumn{4}{|l|}{ Indirect cost (IC) } \\
\hline Engineering and supervision & 0.32 & $0.32 *$ PED & $3,032,739$ \\
\hline Construction expenses & 0.34 & $0.34^{*}$ PED & $3,222,285$ \\
\hline Legal expenses & 0.04 & $0.04^{*}$ PED & 379,092 \\
\hline Contractor's fee & - & $5 \%$ of $\Sigma D C+\Sigma I C$ & $1,931,609$ \\
\hline \multirow[t]{2}{*}{ Contingency } & - & $10 \%$ of $\sum D C+\sum I C$ & $3,863,218$ \\
\hline & & Total indirect plant cost $(\Sigma \mid C)$ & $12,428,943$ \\
\hline Fixed capital investment (FCI) & $44,427,002$ & & \\
\hline Working capital & - & $15 \%$ of $\mathrm{TCl}$ & $7,830,791$ \\
\hline Total capital investment (TCl) & $52,257,793$ & & \\
\hline
\end{tabular}

the energy balance for crystallizer has obtained a percentage error of $120.98 \%$. This result might be due to the difference in the calculations of the heat of crystallisation in manual calculations and SuperPro Designer.

\subsection{Process optimization and heat integration}

The process was optimized by recycling sorbose back to the second fermenter (FR-102) after the filtration process. This was done since the fermenter contains more sorbose than sorbitol, and it will affect the conversion of sorbitol to sorbose if it is recycled back to the first fermenter. The objective function of adding a recycle stream is to minimize waste and to increase production. As a result, the production of ascorbic acid has increased by $24 \%$ after optimization. In terms of purity, the purity of the base case is $99.3 \%$, whereas the purity of recycled process is $99.2 \%$.

Heat integration was performed to minimize the consumption of energy and total operating cost. As mentioned earlier, since the production of ascorbic acid is a batch process, the period where process streams are available for heat exchange might be different. Therefore, heat exchanger network has only performed on process stream that is available for heat exchange at the same time. All hot and cold streams in each time interval are predefined in Table 7. There are two hot streams, which is S-113 and
S-132, and two cold streams, which are S-107 and S-117 are available for heat exchange from $t=101 \mathrm{~h}$ to $t=103 \mathrm{~h}$. Therefore, pinch analysis was performed on these streams from $t=101 \mathrm{~h}$ to $\mathrm{t}=103 \mathrm{~h}$. As a result, the energy consumption had reduced by $2991 \mathrm{GJ}$, which is $20 \%$, with the total cost saved is USD 33,333.

By using Problem Table Algorithm method [24], the hot and cold pinch temperatures can be determined. Firstly, the shifted temperature intervals from original temperature values were calculated by using minimum approach temperature, $\Delta \mathrm{T}_{\min }$ of $10{ }^{\circ} \mathrm{C}$ for all four of the chosen process streams. Then, Energy balance in each shifted temperature intervals was determined. It is followed by performing heat cascade to determine the hot and cold pinch temperatures, as well as minimum hot and cold utilities. The values of hot and cold pinch temperatures are $40{ }^{\circ} \mathrm{C}$ and $30^{\circ} \mathrm{C}$, respectively. Besides, the minimum hot and cold utilities required are $8.1 \times 10^{6} \mathrm{~W}$ and $8.3 \times 10^{5} \mathrm{~W}$, respectively. Consequently, a heat exchanger network for all heat sinks and heat sources (as shown in Fig. 2) can be synthesized using Grid Diagram and Pinch Analysis.

\subsection{Process control philosophy}

For the design of the control system in the plant, plant-wide control philosophy via Luyben "Top Down" 
Table 9 Estimation of operating costs

\begin{tabular}{|c|c|c|c|}
\hline Description & Cost factor & Formula & Base (USD) \\
\hline \multicolumn{4}{|c|}{ Manufacturing: variable production cost (VPC) } \\
\hline Raw material & - & - & $1,307,394$ \\
\hline Operating labour (OL) & - & - & 900,800 \\
\hline Utilities cost & - & SuperPro Designer & 274,915 \\
\hline Operating Supervision (OS) & 0.15 & $0.15^{*} \mathrm{OL}$ & 135,120 \\
\hline Maintenance and Repairs cost (MC) & 0.07 & $0.07 * \mathrm{FCl}$ & $3,109,890$ \\
\hline Operating supplies & 0.15 & $0.15^{*} \mathrm{MC}$ & 466,484 \\
\hline Laboratory charges & 0.1 & $0.1 * \mathrm{OL}$ & 90,080 \\
\hline \multirow[t]{2}{*}{ Royalties } & 0.04 & $0.04 *$ TPC & $1,699,146$ \\
\hline & & Total variable production cost (VPC) (IVPC) & $7,983,828$ \\
\hline Plant overhead cost (POC) & - & $60 \%$ of $\Sigma O L+O S+M C$ & $2,487,486$ \\
\hline \multicolumn{4}{|l|}{ Manufacturing: fixed charges (FC) } \\
\hline Taxes (property) & 0.03 & $0.03^{*} \mathrm{FCl}$ & $1,332,810$ \\
\hline Insurance & 0.01 & $0.01 * \mathrm{FCl}$ & 444,270 \\
\hline Financing (interest) & 0.50 & $0.5^{*} \mathrm{TCl}$ & $26,131,908$ \\
\hline \multirow[t]{2}{*}{ Depreciation } & 0.03 & $0.03 * \mathrm{TCl}$ & $1,567,914$ \\
\hline & & Total fixed charges (FC) ( $(\Sigma F C)$ & $29,476,902$ \\
\hline Total manufacturing cost (TMC) & - & $\mathrm{VPC}+\mathrm{POC}+\mathrm{FC}$ & $39,948,217$ \\
\hline \multicolumn{4}{|l|}{ General expenses (GE) } \\
\hline Administrative expenses & 0.15 & $0.15^{*}(\mathrm{OL}+\mathrm{OS}+\mathrm{MC})$ & 621,872 \\
\hline Distribution and marketing insurance & - & $2 \%$ of TPC & 856,646 \\
\hline \multirow[t]{2}{*}{ Research and development expenses } & - & $5 \%$ of TPC & $2,180,116$ \\
\hline & & Total general expenses (GE) ( $\Sigma \mathrm{GE})$ & $3,658,633$ \\
\hline Total production cost (TPC) & - & $\mathrm{TMC}+\mathrm{GE}$ & $43,606,849$ \\
\hline
\end{tabular}

Table 10 Profitability analysis for base case, best case and worst case

\begin{tabular}{|c|c|c|c|c|}
\hline Description & Formula & Base case & Best case & Worst case \\
\hline Total production Cost (USD/year) & - & $43,606,849$ & $43,275,478$ & $43,836,015$ \\
\hline Total capital investment (USD/year) & & $52,257,793$ & & \\
\hline Total annual revenue (USD/year) & & $85,754,546$ & $102,905,455$ & $68,603,637$ \\
\hline Salvage (USD/year) & $0.1 *$ Total capital Investment & $5,225,779$ & & \\
\hline Depreciation (USD/year) & Fixed capital Investment - Salvage & $39,201,222$ & & \\
\hline Average depreciation (USD/year) & Depreciation/service years & $1,960,061$ & & \\
\hline Corporate tax rate* $(\%)$ & - & 0.31 & 0.25 & 0.37 \\
\hline Gross profit (USD/year) & Total production cost - total annual revenue & $42,147,696$ & $59,629,977$ & $24,767,622$ \\
\hline Net profit (USD/year) & $\left(1\right.$-tax rate) ${ }^{*}$ gross profit & $29,081,911$ & $41,144,684$ & $17,089,659$ \\
\hline Return on investment (\%) & (Net profit/total capital investment) $* 100$ & 55.65 & 78.73 & 32.70 \\
\hline Payback period (years) & Total capital investment/net profit & 1.80 & 1.17 & 3.36 \\
\hline Net present value (USD/year) & Net cash flow/service years & $10,599,474$ & $17,272,930$ & $8,549,144$ \\
\hline
\end{tabular}

${ }^{*}$ Corporate tax rate is inclusive of sales and services tax implemented by Malaysia's government on 1st September 2018

approach is performed to meet the control objectives for the overall process. The control objectives for the plant are:
1. to achieve production capacity of 500 tonne per year

2. to control of reactant ratio to minimize waste and increase reaction conversion 
Fig. 4 Cumulative cash flow diagram for base, best and worst case
Fig. 5 Sensitivity analysis curve

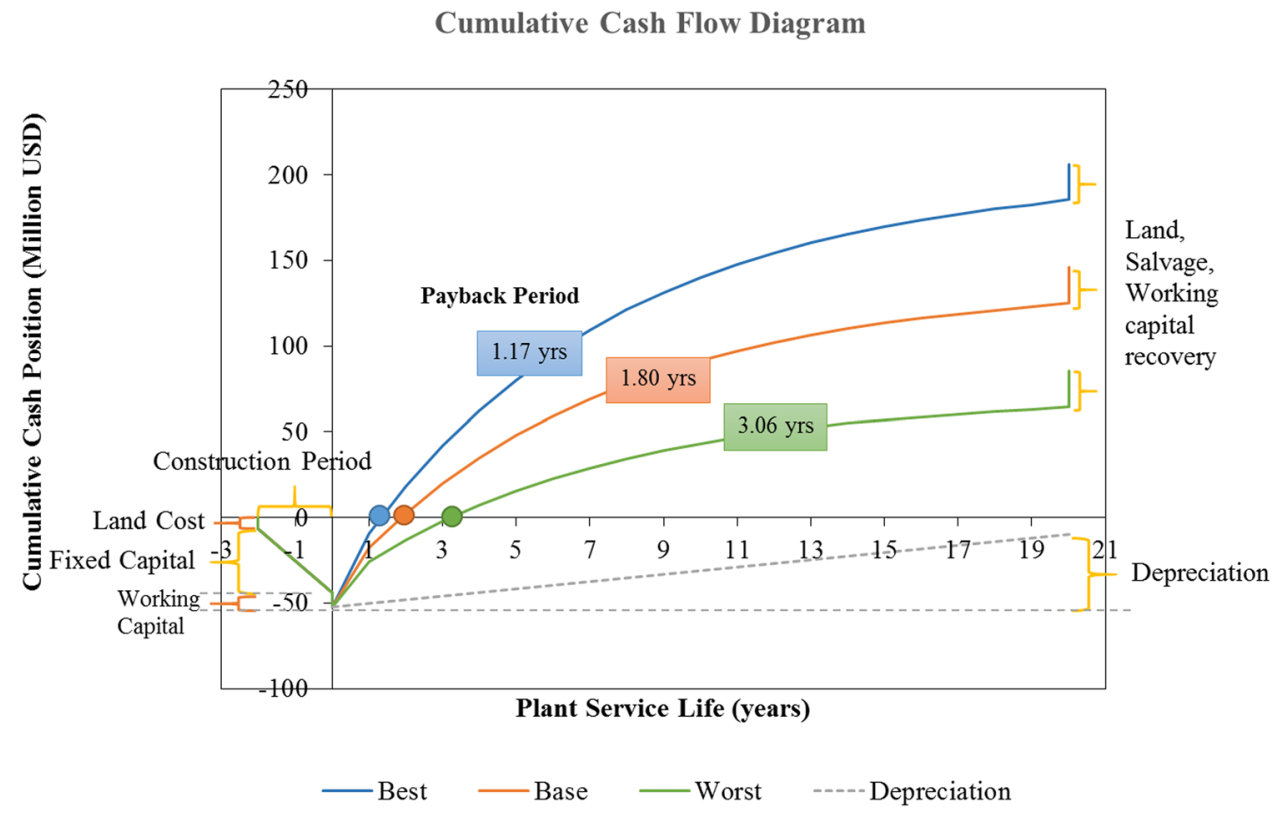

Sensitivity Analysis

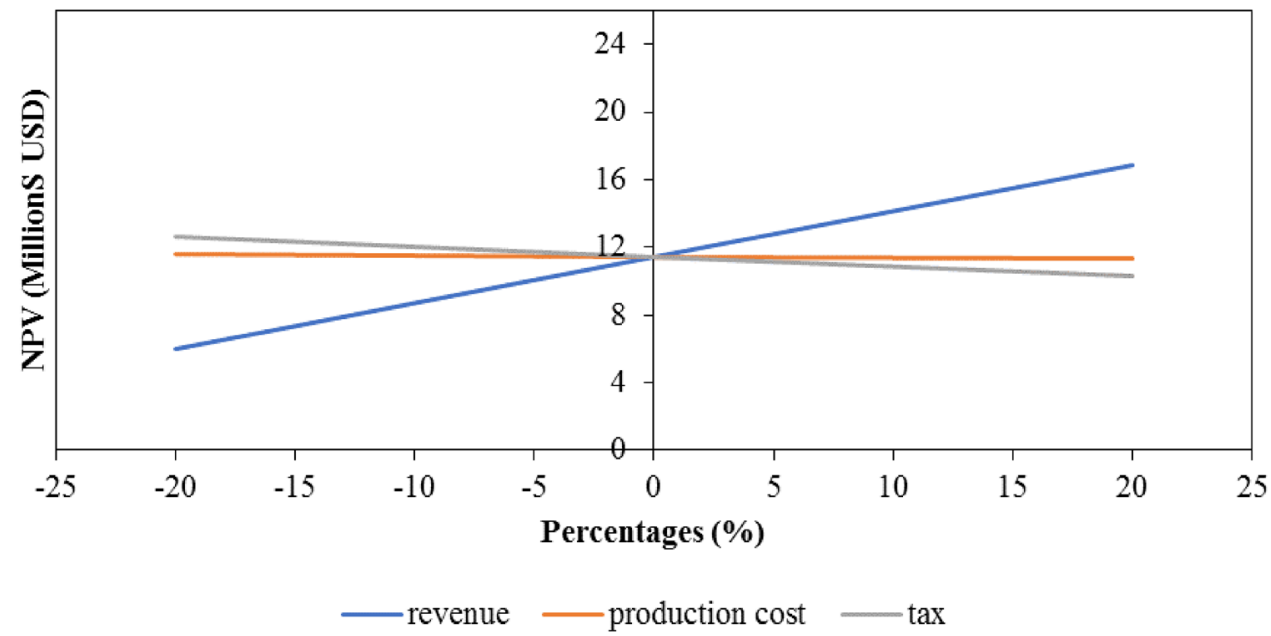

3. to control of microenvironment for bacterial fermentation as the performance of bacteria is strongly dependent on the microenvironment

4. to achieve product specification of $95 \%$ purity

5. to maximize heat exchange between process stream to minimize energy consumption

6. to control of optimum operating conditions

7. to ensure safe operation

Parameters such as temperature, pressure, flow, level, composition, $\mathrm{pH}$ and dissolved oxygen are being controlled to meet the above control objectives. These parameters are controlled by using a feedback control scheme where some of them are associated with cascade, ratio and override control scheme. Cascade control system is used to handle disturbances such as flow rate before it affects the process significantly. Besides, a ratio controller is used to determine the flow rate of one stream with respect to a second stream based on the objective of the system itself. Also, the override control scheme will be used when there is a safety concern, such as to stop the flow of low-pressure steam when the pressure within the 
heater is too high. The detailed P\&ID for this plant design is shown in Fig. 3.

\subsection{Economic analysis for capital and operating costs}

Before the calculation of total capital investment cost, cost estimation was done. The total bare module cost of the two main fermenters was calculated to be around USD 5.56 million while the two CSTRs were approximately USD 2 million. Due to the huge production of Vitamin C via a batch process, the larger size of equipment is designed. Total bare module cost calculated for all the equipment, including the conveyor used for solids transportation was approximately USD 14 million. The capital cost investment for the plant is high, but the profits are covered up with the high selling price of Vitamin C produced. Next, the estimation of labor cost, which is the annual salary calculated for all workers in the plant, including the salaries for manager and engineers was USD 0.88 million. The cost estimation was done in compliance with Malaysia's new labor law in Employment Act 1955, which requires employers to pay a minimum wage of USD 245 per month.

On the other hand, Table 8 shows the calculation of total capital investment cost by using the Lang Factors method. The cost of the land for the plant, which is located at Perai Industrial Estate, Penang, Malaysia (the northwest coast of Peninsular Malaysia) was obtained from a local property-related website, namely "iProperty". The plant is located strategically with the main supplier of raw material, Prima Inter-Chem. As shown in Table 8, the total direct cost calculated was USD 126.77 million, whereas for indirect cost was approximately USD 12.43 million. Meanwhile, the total approximated $\mathrm{FCl}$ for the plant designed was approximately USD 52.22 million with the working capital of USD 7.78 million.

The total costs for instrumentation and control were calculated based on the P\&ID drawn. In the plant, different types of transmitter, controller and valves were used for safety purposes. Meanwhile, each instrument cost with different specifications of the instrumentations was obtained from Alibaba online, and the total cost of the instrument obtained was approximately USD 30,233 . On the other hand, the cost of utilities used around the plant site was also evaluated. The heat duty used was obtained from SuperPro Designer, and it is compared with the manual calculation of the heat duty. Since a total of 33 batches per year is assumed, the total utilities estimated were USD 0.22 million. As shown in Table 9, the calculated TPC was approximately USD 43.56 million annually. Depreciation of equipment was included during the calculation of the total production cost. The total depreciation was approximately USD 1.56 million, which equivalent to $3 \%$ of the $\mathrm{TCl}$. The total operating cost was calculated based on 330 working days, with a total of 33 batches per year.

\subsection{Profitability analysis}

As mentioned before, the economic analysis is assessed based on three scenarios, which are the base case, the best case, and the worst case. The best case indicates a $20 \%$ increase of the product selling price, $20 \%$ decrease of the raw material cost, and $20 \%$ decrease of tax rate. The worst case is when the product selling price decreases by $20 \%$, the raw material cost increase by $20 \%$, and the tax rate also increases by $20 \%$. The profitability analysis for these three different cases is generated and shown in Table 10. The cumulative cash flow diagram for these three cases was shown in Fig. 4. Notice that the base case has a payback period of 1.80 years, $55.65 \%$ of return on investment, and USD 29.11 million net profit. And, the best case has a payback period of 1.17 years, $78.73 \%$ of return on investment, and USD 41.11 million net profit. Meanwhile, the worst case has a payback period of 3.36 years, $32.70 \%$ of return on investment, and USD 17.11 million net profit.

\subsection{Sensitivity analysis}

Sensitivity analysis was conducted to determine how a different value of independent variables affect the dependent variable. Moreover, it is used to investigate the sensitivity of project profitability towards various economic factors [25]. For this analysis, the independent variables are the total annual revenue, production cost, and tax rate. Meanwhile, the dependent variable is the net present value (NPV). The independent variables were adjusted by increasing or decreasing the base case value by $20 \%$ to conduct the sensitivity analysis. Then, the sensitivity analysis result is shown in Fig. 5. From the analysis, it can be concluded that the revenue obtained from the selling of ascorbic acid and by-product of sodium hydroxide affects the most to the net present value, while the production cost determined by the raw material cost affects the least.

As a summary, a series of economic analysis was undertaken to study the feasibility of ascorbic acid production plant in terms of investment concern. The market survey of ascorbic acid highlights that this investment exhibits high potential due to the increasing awareness towards a 
healthy lifestyle. Furthermore, the payback period of the worst scenario is 3.36 years. This indicates that the high selling price of ascorbic acid can cope with the fluctuations in the market. Thus, the production plant of ascorbic acid designed can meet the business concern of stakeholders.

\section{Conclusion}

In conclusion, this designed plant is expected to yield an annual production of 500 tonne ascorbic acid (Vitamin C) with a minimum purity of $95 \%$. Besides ascorbic acid as the main product, the plant also produces two byproducts, that are sodium hydroxide and carbon dioxide. Two-step fermentation with a single culture was chosen as it requires low production cost, less energy, and water consumption. This technology also eases the controlling and monitoring work on the fermentation process. The feasibility study of ascorbic acid production was performed through simulation using SuperPro Designer. Also, economic and sensitivity analysis was conducted on the ascorbic acid plant design.

In addition, profitability analysis was performed by adjusting parameters of the market condition, which are products' selling price, raw material cost, and taxation rate. The best case of profitability analysis was conducted under conditions of $20 \%$ increment in product selling price, a $20 \%$ decrease in raw material cost and the tax rate. Thus, the total annual revenue and NPV for the best case scenario are USD 102.89 million and USD 7817.33 million, respectively. TPC is USD 43.11 million with an $\mathrm{ROI}$ of $78.72 \%$, and a payback period of 1.2 years. For the worst case, the product selling price is decreased by $20 \%$, where raw material and the tax rate is increased by $20 \%$. The condition of the worst scenario will yield total revenue and NPV of USD 68.67 million and USD 8.45 million with a payback period of 3.4 years. Hence, by considering both of the best and worth cases, this designed plant is worth to be invested and set up.

Acknowledgements The authors would like to thank Curtin University Malaysia for providing the financial support for this project through the final year funding scheme. This research did not receive any specific grant from funding agencies in the public, commercial, or not-for-profit sectors.

\section{Compliance with ethical standards}

Conflict of interest The authors have no conflicts of interest to declare.

\section{Appendix}

See Fig. 6, Tables 11, 12 and 13.

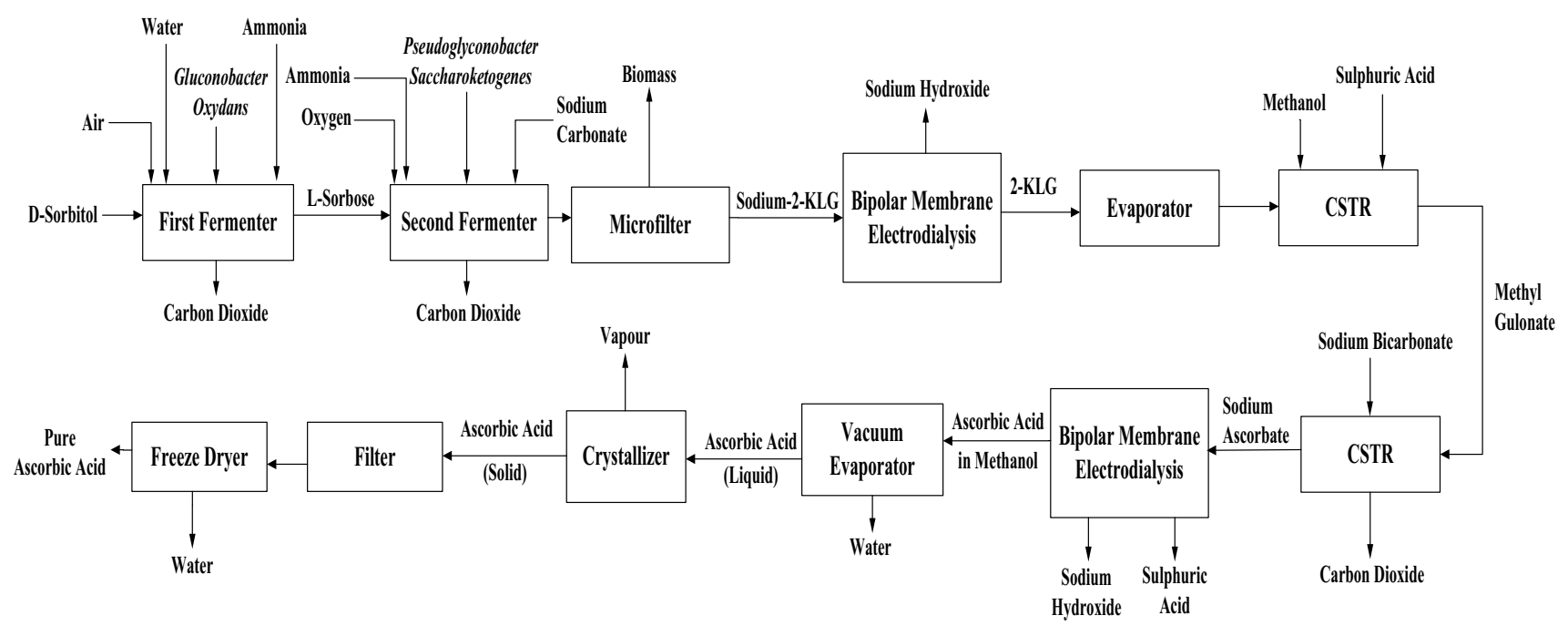

Fig. 6 Process flow diagram of two-step fermentation process 
Table 11 Summary cost of with and without by-products for two-step fermentation process

\begin{tabular}{|c|c|c|c|c|c|c|}
\hline Component i & $\begin{array}{l}\text { Stoichio-metry } \\
v_{i}\end{array}$ & $\begin{array}{l}\text { Molecular } \\
\text { weight } \mathrm{M}_{\mathrm{i}}\end{array}$ & $\mathrm{v}_{\mathrm{i}} \mathrm{M}_{\mathrm{i}}$ & $\begin{array}{l}\mathrm{v}_{\mathrm{i}} \mathrm{M}_{\mathrm{i}} \times \mathrm{SF}^{*} \\
\text { (tonne/year) }\end{array}$ & Price (USD) & $\begin{array}{l}\mathrm{V}_{\mathrm{i}} \mathrm{M}_{\mathrm{i}} \times \mathrm{SF}^{*} \times \text { Price } \\
\text { (USD/year) }\end{array}$ \\
\hline $\mathrm{C}_{6} \mathrm{H}_{14} \mathrm{O}_{6}$ & -1 & 182.17 & -182.17 & -1416.90 & 93,333 & $-132,243,528$ \\
\hline $\mathrm{O}_{2}$ & -0.5 & 16.00 & -8.00 & -62.22 & - & \\
\hline $\mathrm{Na}_{2} \mathrm{CO}_{3}$ & -0.5 & 105.99 & -52.99 & -412.18 & 175,556 & $-72,360,672$ \\
\hline $\mathrm{NaHCO}_{3}$ & -1 & 84.01 & -84.01 & -653.39 & 11,222 & $-7,332,343$ \\
\hline $\mathrm{C}_{6} \mathrm{H}_{8} \mathrm{O}_{6}$ & 1 & 176.12 & 176.12 & 1369.86 & 882,222 & $1,208,520,629$ \\
\hline $\mathrm{NaOH}$ & 2 & 40.00 & 79.99 & 622.18 & 222,222 & $138,262,084$ \\
\hline $\mathrm{H}_{2} \mathrm{O}$ & 2.5 & 18.02 & 45.04 & 350.30 & 104,000 & $36,431,200$ \\
\hline $\mathrm{CO}_{2}$ & 1.5 & 44.01 & 66.02 & 513.45 & Reused as refrigerant & \\
\hline \multirow[t]{2}{*}{$\begin{array}{l}\text { Scale factor, SF*: } \\
=\frac{500000 \frac{\text { tonne }}{\text { year }} \mid \frac{\text { year }}{365 \text { days }}}{176.12}=7.7778 \\
\text { Fractional atom economy: } \\
=\frac{176.12}{-(-182.17-8.00-52.99-84.01)}=0.5383\end{array}$} & $\begin{array}{l}\text { Total cost with } \\
\mathrm{H}_{2} \mathrm{O}, \mathrm{NaOH} \\
\text { and } \mathrm{CO}_{2} \\
\text { (USD/year) }\end{array}$ & $\begin{array}{l}\text { USD } \\
1,171,277,370\end{array}$ & & & & \\
\hline & $\begin{array}{l}\text { Total cost } \\
\text { without } \mathrm{H}_{2} \mathrm{O} \text {, } \\
\mathrm{NaOH} \text { and } \\
\mathrm{CO}_{2} \text { (USD/ } \\
\text { year) }\end{array}$ & $\begin{array}{l}\text { USD } \\
\quad 996,584,086\end{array}$ & & & & \\
\hline
\end{tabular}

Table 12 Thermodynamics properties of each component [19]

\begin{tabular}{|c|c|c|c|c|c|c|c|c|c|}
\hline \multirow[t]{2}{*}{ Components } & \multirow[t]{2}{*}{$\begin{array}{l}\text { Heat of } \\
\text { formation (J/ } \\
\text { gmol) }\end{array}$} & \multicolumn{4}{|c|}{ Gaseous $\mathrm{Cp}=\mathrm{A}+\mathrm{BT}+\mathrm{CT}^{2}+\mathrm{DT}^{3}$} & \multirow{2}{*}{$\begin{array}{l}\text { Cp for } \\
\text { liquid/ } \\
\text { solid (J/ } \\
\text { gmol K) }\end{array}$} & \multirow{2}{*}{$\begin{array}{l}\text { Critical } \\
\text { tempera- } \\
\text { ture, Tc } \\
\left({ }^{\circ} \mathrm{C}\right)\end{array}$} & \multicolumn{2}{|c|}{$\begin{array}{l}\text { Heat of vaporisation, } \mathrm{J} / \\
\mathrm{gmol} \Delta H v=a\left(1-\frac{T}{T c}\right)^{b}\end{array}$} \\
\hline & & $A$ & B & $\mathrm{C}$ & $\mathrm{D}$ & & & a & $\mathrm{b}$ \\
\hline Sorbitol & $-1,354,150$ & 57.14 & $7.70 \times 10^{-1}$ & $-5.45 \times 10^{-4}$ & $1.61 \times 10^{-7}$ & 332.20 & 594.85 & 209,200 & 0.33 \\
\hline Oxygen & 0 & 28.11 & $-3.00 \times 10^{-6}$ & $1.75 \times 10^{-5}$ & $-1.07 \times 10^{-8}$ & 97.00 & -118.39 & 9557.08 & 0.36 \\
\hline Sorbose & $-1,276,900$ & 71.45 & 1.27 & $-1.23 \times 10^{-3}$ & $4.49 \times 10^{-7}$ & 228.61 & 767.86 & $40,411.71$ & 0.35 \\
\hline Water & $-285,830$ & 32.24 & $1.92 \times 10^{-3}$ & $1.06 \times 10^{-5}$ & $-3.60 \times 10^{-9}$ & 75.24 & 374.19 & $60,334.52$ & 0.41 \\
\hline Sodium carbonate & $-1,130,770$ & 13.98 & $5.44 \times 10^{-2}$ & $-3.13 \times 10^{-5}$ & 0 & 189.54 & -273.15 & 0 & 0 \\
\hline $\begin{array}{l}\text { Sodium keto-glu- } \\
\text { conic acid }\end{array}$ & $-1,164,600$ & & 0.56 & $-3.73 \times 10^{-4}$ & $9.64 \times 10^{-8}$ & 305.40 & 509.85 & 199,700 & 0.33 \\
\hline Carbon dioxide & $-393,510$ & 19.80 & $7.34 \times 10^{-2}$ & $-5.60 \times 10^{-5}$ & $1.72 \times 10^{-8}$ & 209.53 & 31.03 & $24,570.69$ & 0.40 \\
\hline Keto-gluconic acid & $-1,164,600$ & 80.39 & 0.56 & $-3.73 \times 10^{-4}$ & $9.64 \times 10^{-8}$ & 305.40 & 509.85 & 199,700 & 0.33 \\
\hline Sodium hydroxide & $-425,930$ & 43.57 & $1.76 \times 10^{-2}$ & $-7.56 \times 10^{-6}$ & $1.09 \times 10^{-9}$ & 87.18 & 2546.85 & 0 & 0 \\
\hline Methanol & $-239,100$ & 21.15 & $7.09 \times 10^{-2}$ & $2.59 \times 10^{-5}$ & $-2.85 \times 10^{-8}$ & 81.60 & 239.42 & $58,450.42$ & 0.41 \\
\hline Methyl gluconate & $-1,164,600$ & 80.39 & 0.56 & $-3.73 \times 10^{-4}$ & $9.64 \times 10^{-8}$ & 305.40 & 509.85 & 199,700 & 0.33 \\
\hline Sodium bicarbonate & $-950,810$ & 10.97 & $3.37 \times 10^{-2}$ & 0 & 0 & 90.00 & -273.15 & 0 & 0 \\
\hline Sodium ascorbate & $-1,164,600$ & 80.39 & 0.56 & $-3.73 \times 10^{-4}$ & $9.64 \times 10^{-8}$ & 305.40 & 509.85 & 199,700 & 0.33 \\
\hline Ascorbic acid & $-1,164,600$ & 80.39 & $5.64 \times 10^{-1}$ & $-3.73 \times 10^{-4}$ & $9.64 \times 10^{-8}$ & 305.40 & 509.85 & 199,700 & 0.33 \\
\hline Ammonia & $-45,898$ & 27.31 & $2.38 \times 10^{-2}$ & $1.71 \times 10^{-5}$ & $-1.19 \times 10^{-8}$ & 80.00 & 132.39 & $34,403.33$ & 0.40 \\
\hline Nitrogen & 0 & 31.15 & $-1.33 \times 10^{-2}$ & $2.68 \times 10^{-5}$ & $-1.17 \times 10^{-8}$ & 88.80 & -146.90 & 7900.94 & 0.36 \\
\hline Biomass & 0 & 0.00 & 0 & 0 & 0 & 103.00 & 374.15 & 0 & 0 \\
\hline
\end{tabular}

$\mathrm{Cp}$ is the specific heat capacity and $\mathrm{T}$ is the temperature in Celsius 
Table 13 Stream table from Superpro Designer

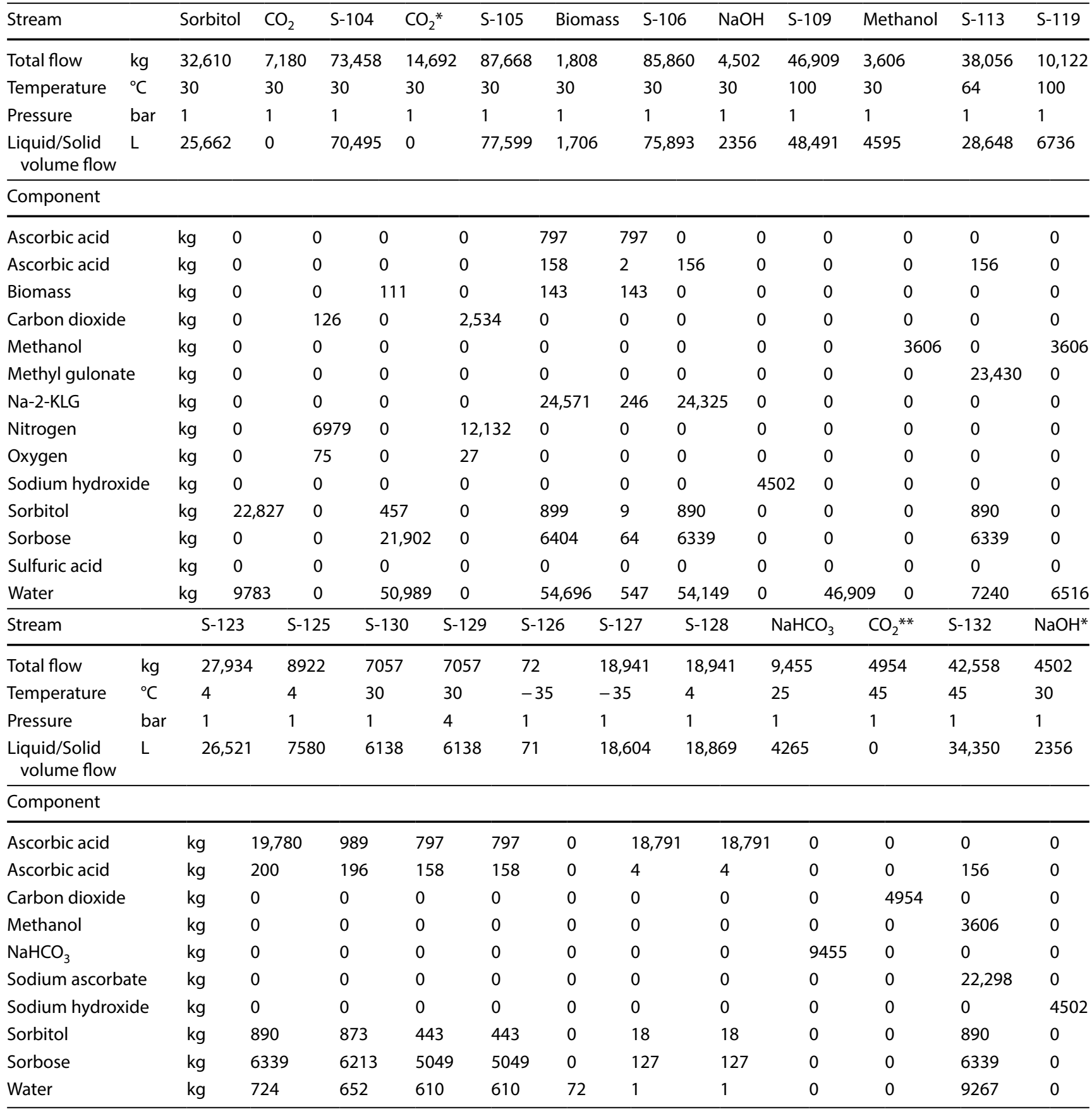

$\mathrm{CO}_{2}{ }^{*}$ is the carbon dioxide releases from fermenter 2, FR-102

$\mathrm{CO}_{2}{ }^{* *}$ is the carbon dioxide releases from CSTR 2, R-102

$\mathrm{NaOH}^{*}$ is the sodium hydroxide releases from bipolar membrane electrodialysis, GBX-101

\section{References}

1. Córović M, Milivojević A, Carević M, Banjanac K, Jakovetić Tanasković S, Bezbradica D (2017) Batch and semicontinuous production of L-ascorbyl oleate catalyzed by CALB immobilized onto Purolite ${ }^{\oplus}$ MN102. Chem Eng Res Des 126:161-171
2. Hancock R, Viola R (2001) The use of micro-organisms for L-ascorbic acid production: current status and future perspectives. Appl Microbiol Biotechnol 56(5-6):567-576

3. Boudrant J (1990) Microbial processes for ascorbic acid biosynthesis: a review. Enzyme Microb Technol 12(5):322-329

4. Xu A, Yao J, Yu L, Lv S, Wang J, Yan B (2004) Mutation of Gluconobacter oxydans and Bacillus megaterium in a two-step 
process of L-ascorbic acid manufacture by ion beam. J Appl Microbiol 96(6):1317-1323

5. Department of Environment Malaysia (2012) Guidelines for siting and zoning of industry and residential areas. https:// www.doe.gov.my/portalv1/en/. Accessed 11 Nov 2018

6. Bohnet M C, Ullmann F (2003) Ullmann's encyclopedia of industrial chemistry, German

7. Yang W, Xu H (2016) Industrial fermentation of vitamin C. Ind Biotechnol Vitamins, Biopigments, and Antioxidants

8. Giridhar R, Srivastava AK (2006) Fed-batch cultivation of Acetobacter suboxydans for the microbial oxidation of D-sorbitol to L-sorbose. Bioprocess Eng 23(6):575-577

9. Survase SA, Bajaj I, Singhal R (2006) Biotechnological production of vitamins. Food Technol Biotechnol 44(3):381-396

10. National Research Council (1992) Applications of biotechnology to traditional fermented foods: report of an ad hoc panel of the Board on Science and Technology for International Development/Office of International Affairs. National Academy Press, Washington

11. Raghavan GN, Srivastava AK (2002) Productivity improvement in L-sorbose biosynthesis by fed-batch cultivation of Gluconobacter oxydans. J Biosci Bioeng 94(1):34-38

12. Shibata $T$, Ishii $Y$, Noguchi $Y$, Yamada $H$, Saito $Y$, Yamashita $M$ (2001) Purification and molecular characterization of a quinoprotein alcohol dehydrogenase from Pseudogluconobacter saccharoketogenes IFO 14464. J Biosci Bioeng 92(6):524-531

13. Vandamme EJ, Revuelta JL (2016) Industrial biotechnology of vitamins, biopigments, and antioxidants. Wiley, Hoboken

14. Lee H, Pan JG (1999) Screening for L-sorbose and L-sorbosone dehydrogenase producing microbes for 2-keto-L-gulonic acid production. J Ind Microbiol Biotechnol 23(2):106-111

15. Pal P, Kumar R, Banerjee S (2016) Manufacture of gluconic acid: a review towards process intensification for green production. Chem Eng Process Process Intensif 104:160-171

16. Andreas W B (2000) Method for the production of L-ascorbic acid by lactonization of 2-keto-L-gulonic acid or \$2-keto-L-gulonate esters. US patent 7,091,375
17. Xu B, Zheng X, Zhang W, Zhang X, Zhang Z, Shang H (2008) Kinetics of esterification of 2-keto-L-gulonic acid with methanol catalyzed by cation exchange resin. Trans Tianjin Univ 14(1):37-42

18. Langrish TAG (2008) Degradation of vitamin c in spray dryers and temperature and moisture content profiles in these dryers. Food Bioprocess Technol 2:400

19. Sonntag RE, Borgnakke C, Van Wylen GJ, Van Wyk S (1998) Fundamentals of thermodynamics, vol 6. Wiley, New York

20. Hatamleh MT, Hiyassat M, Sweis GJ, Sweis RJ (2018) Factors affecting the accuracy of cost estimate: case of Jordan. Eng Constr Archit Manag 25(1):113-131

21. Towler G, Sinnott R (2012) Chemical engineering design: principles, practice and economics of plant and process design. Elsevier, Amsterdam

22. Sinnott RK (2009) Chemical engineering design. ButterworthHeinemann, Oxford

23. Rezaei E, Dzuryk S (2019) Techno-economic comparison of reverse water gas shift reaction to steam and dry methane reforming reactions for syngas production. Chem Eng Res Des 144:354-369

24. Kemp IC (2007) Pinch analysis and process integration: a user guide on process integration for the efficient use of energy. Butterworth-Heinemann, Oxford

25. Perry RH (2008) Perry's chemical engineer's handbook. McGraw Hill, New York

Publisher's Note Springer Nature remains neutral with regard to jurisdictional claims in published maps and institutional affiliations. 